\title{
Structural change and domestic technological capabilities
}

\author{
Jorge Katz
}

$\mathrm{T}$

his paper examines the role of structural change as a source of economic growth and institutional and technological change. With the creation of new activities in the economy, significant changes occur in institutions and in the way domestic production capabilities are organized, which alters the ultimate sources of growth in society. This is a complex process that involves ubiquitous externalities and new forms of clustering and direct interdependence between economic agents that the language of modern growth theory cannot fully capture. Neoclassical growth models construe economic growth in terms of an institution-free equilibrium algorithm that affords insufficient consideration to macro-to-micro interactions, changes in the structure of production, the co-evolution of economic, institutional and technological forces and the process of creation and destruction of production organization capabilities that obtains in the economy during the growth process. This paper argues that precisely these macro-to-micro interactions and the creation of new institutions and capabilities constitute the essence of development. 


\section{I}

\section{Introduction}

For more than three decades now, Latin American countries have conducted market-oriented structural reforms, opening up their economies to foreign competition, de-regulating markets, and privatizing economic activities, at different times and with varying degrees of success. These policy reforms represented a major departure from the inward-oriented, State-led regimes that prevailed in the immediate post-war period. The new policies -together with the rapid globalization of the world economy in the 1990sworked a major transformation of the economic, institutional and technological environment in each of the countries. The structure of production and the operation of the institutional and socio-economic model has changed significantly in the Latin American countries and this, in turn, has affected growth, international competitiveness, equity and the development of domestic technological capabilities.

The neoclassical approach is not particularly useful for examining these issues. Modern growth theory construes economic growth in terms of an institutionfree equilibrium algorithm that affords insufficient consideration to macro-to-micro interactions, changes in the structure of production, the co-evolution of economic, institutional and technological forces and the process of creation and destruction of production organization capabilities that occurs in the economy during the growth process. In our view, macro-to-micro interactions and the creation of new institutions and capabilities are crucial to understanding what economic development is all about.

The legacy of market-oriented reforms has fallen short of the expectations that policymakers and academic economists held in the 1970s, when these reforms were first promoted. This is clearly apparent from a comparison of recent GDP growth rates, international competitiveness and the economy's

\footnotetext{
$\square$ An earlier version of this article was presented at the seminar on "Economic growth with equity: challenges for Latin America" (Santiago, Chile, 1 and 2 September 2005), organized by the Economic Commission for Latin America (ECLAC), with the support of the Ford Foundation and the German Agency for Technical Cooperation (GTZ).
}

capacity to create new jobs and to distribute the benefits of growth equitably among different walks of society, vis-à-vis the post war decades. Domestic technological capabilities have been hugely transformed by the destruction and creation of production capacity, yet they remain fragmentary and sorely insufficient throughout the region.

In all of the dimensions mentioned -growth, competitiveness, equity and the building up of domestic technological capabilities- the new Latin American economic model yielded much poorer results than expected (Katz, 2002 and 2003). Furthermore, notwithstanding the bonanza the region is currently enjoying thanks to buoyant world demand and high international prices for foodstuffs, raw materials and industrial commodities (what might be termed the "China effect"), the indiscriminate adoption of Washington Consensus ideas has left most of the region's countries still lacking an adequate long-term growth strategy that could simultaneously secure higher rates of economic expansion, reduce macroeconomic volatility, enhance competitiveness in world markets and yield greater equity and a more satisfactory overall technological and innovative performance. And yet, without such a strategy and performance, the Latin American countries will be hard put to narrow the productivity and income gap that separates them from the more developed industrial nations.

Throughout the 1990s, new sectors of economic activity emerged and many "old" ones were gradually phased out. Labour was pushed out of both manufacturing and agriculture and the informal sector of the economy expanded rapidly in most Latin American countries. The re-absorption of labour has not only been slowed by a low investment-to-GDP ratio, but has been further hampered by the transition to an environment in which production is organized digitally. The larger firms in the economy, many of them subsidiaries of TNCs or owned by local conglomerates, brought on board different forms of capital intensive, computer-based technologies for production organization, displacing old, more labour-intensive technologies and forms of organization. This process introduced a strong labour-saving bias into the economy. Most SMEs have not reacted well to the new 
rules of the game because of capital market imperfections, a lack of technological capabilities or an imperfect understanding of the new responses required by a more open and deregulated macroeconomic policy regime. Thousands of SMEs were forced out of the market (with the closure of an estimated 8,000 SMEs in Chile and over 12,000 in Argentina in the 1980s), while the great majority of those remaining in business found themselves lagging behind large corporations in terms of productivity growth and innovation. One result of this is that average labour productivity in Latin America remains rather low by international standards. In fact, it is still apparently between $20 \%$ and $50 \%$ of average labour productivity in the United States, with Argentina and Chile in the upper part of the range and Ecuador, Paraguay and Bolivia in the lower part (Katz, 2003).

It may justifiably be argued that the marketoriented reforms and the process of world economic globalization of the last two decades have induced a major Schumpeterian episode of creation and destruction of production capacity, significantly altering the production structure and patterns of social organization. Business concentration has increased and so has the influence of foreign-owned firms in the economy. It is increasingly evident that large firms adapted better to the new policy environment than SMES did, and the labour productivity gap between the two types has expanded significantly.

Even though the reforms have not delivered what they were expected to, they have nevertheless resulted in the emergence of a modern sector of economic activity in each of the region's countries. This sector accounts for some $40 \%$ of GDP in the richest countries and little more than some $10 \%$ in the poorest ones. It features new productive activities that were either absent from the economy just a few years ago or were performed using less modern technologies. These new activities include: (i) natural-resource-processing activities which now employ state-of-the-art technologies, such as genetically modified soybean and vegetable oil production in Argentina, salmon farming and winegrowing in Chile, fresh flowers in Colombia, and many others; (ii) high-productivity service industries including banks, telecoms, energy and tourism; and (iii) a few technology-intensive manufacturing activities, such as aeronautical design and construction in Brazil, or the assembly -mostly from imported parts and components- of motor vehicles and electronic equipment in Mexico.
Labour productivity has evolved at a much slower pace as an overall average than it has in the modern section of the economy, however. As far as average labour productivity is concerned, the region compares rather poorly with more developed industrial nations or with East Asian countries, many of which increased their long-term labour productivity throughout the 1990s. Thus, for the economy as a whole, the labour productivity gap vis-à-vis the more developed industrial economies remains as large as it was two decades ago.

The small fraction of society located in the modern sector of the economy enjoys well-above-average incomes and has gradually developed consumption patterns comparable to the great majority of citizens in developed industrial nations. For the individuals in this part of society, the question of whether convergence will ever occur is merely rhetorical, insofar as their lifestyle is quite similar to that of the citizens of, say, Madrid or Rome. Clearly, however, deeper and more intractable forms of social and economic exclusion have emerged in society and levels of informality and open unemployment are higher than in the past. A more confrontational variety of social relations -which has grown out of a climate of mounting frustration and despair- is now widespread, making political governance an increasingly difficult proposition in many Latin American countries.

This paper will look at the role of structural change as a source of economic, institutional and technological development. The importance of structural change as part of the development process, which is examined in Section II, was explicitly acknowledged by classical economists. It has been relegated to a secondary position in modern neoclassical growth models, however, which tend to construe economic growth in terms of an aggregate, economy-wide, institution-free algorithm and do not properly factor in structural change, macro-to-micro interdependencies or the coevolution of economic, institutional and technological forces typical in the economic development process. Section III considers the empirics of this argument, showing the extent to which structural change has been a major force in Latin American growth in the past few decades. Section IV examines local technology generation in the region and section $\mathrm{v}$ looks at possibilities for technological development and innovation policies.

With the emergence of new activities in the economy, institutions and domestic production organization capabilities have changed significantly, affecting the ultimate sources of growth in society. 
This is a complex process that involves ubiquitous externalities and new forms of clustering and direct interdependence among economic agents and public sector organizations, such as regulatory agencies, universities and municipal authorities, which the language of modern growth theory is inadequate to express. For all its highly stylized and elegant presentation, such theory simply lacks the ability to illuminate major details of the process. In order to shed light on these phenomena, we look at two specific cases in Argentina and Chile. In the case of Argentina, we examine the recent development of the genetically modified soybean and vegetable oil industry; in the case of Chile we look at salmon farming. We will show that the emergence of these new activities in the economy has been associated with the development of new institutions, new forms of clustering and the gradual expansion of domestic production organization capabilities which, as classical economists have always argued, constitute the essence of economic development -the ultimate explanation of how it occurs.
Although new production activities have been successfully incorporated into the economy in the recent past, structural transformation in Latin American economies has been rather slow and average labour productivity has remained in the range of $30 \%$ to $50 \%$ of the figure in more developed industrial nations. Similarly, R\&D expenditure is still just a quarter of the amount developed and emerging countries spend on creating and adopting new technologies. The diffusion of ICTs is still in its infancy in Latin America, since they reach only about a third of the population. Only the large firms in the economy have so far adopted computer-based SCM (supply chain management) and CRM (customer relationship management) techniques in their day-to-day operations. Thus, the transition to modernity is still fragmentary and unsatisfactory.

This state of affairs can be traced back to different forms of market failure and to the lack of public goods that could induce a faster rate of innovation and spur technology creation. If they are to achieve gains in innovation and productivity growth, Latin American economies need proactive government strategies and many new forms of public-private coordination.

\section{II}

\section{Structural change as a source of economic growth}

In the classical tradition, which was brought back into vogue in the post-war period by such authors as S. Kusnetz, G.W.E. Salter, M. Abramovitz, N. Kaldor and, more recently, R. Nelson, S. Winter and P. Saviotti and J. L. Gaffard, structural change is considered a powerful source of economic growth. It is associated with more "roundaboutness" in the economy and with increasing returns to scale derived from specialization. A growing economy is one that becomes more complex and sophisticated as new sectors of economic activity are created and as new, more knowledge-intensive firms enter it. Concomitantly, new institutions, skills, and learning processes develop right across the productive and social structure. This is the process that led Kusnets and Abramovitz to differentiate between "immediate" and "ultimate" sources of economic growth. They view an expanding capital-to-labour ratio -resulting from a higher rate of investment to GDP- as an "immediate" source of growth, while learning, the accumulation of domestic technological capabilities, institutional changes and the improvement of production organization capabilities are "ultimate" sources of economic and social development and represent hidden social forces at work under the surface. That we do not normally measure these -indeed, in many cases, we do not even know how to do so- in no way refutes their existence or negates them as the essence of development.

In this light, we believe that the long-term performance of any given economy should not be described exclusively in macro terms but rather as the outcome of the interaction between the macro and the micro and the co-evolution of economic, institutional and technological forces that converge in the process of economic development. Development (as opposed to growth) is associated essentially with the inception of new activities in the economy. It is not solely the action of good management of macroeconomic 
variables upon expectations and upon the rate of capital formation; rather, it is a more complex social phenomenon in which institutional changes, changes in the division of labour (more roundaboutness in the economy), learning processes and the expansion of production organization capabilities are fundamental. Of course, macroeconomic stability is essential for these processes, but it should not be regarded as a sufficient condition in itself.

Many of these changes in the ultimate sources of growth converge in the process of inception of new activities in the economy. As production capacity expands, learning processes are triggered and new institutions (understood as long-term habits and patterns of social interaction among economic agents) emerge. The start-up of new activities is at the root of longterm transformation of society.

Contrary to conventional growth theory, which treats the production structure as given and construes its expansion over time as occurring along a balanced trajectory (like an expanding balloon -to borrow the illuminating metaphor used by A. Harberger (1998)in which the relative size of each part of the structure remains unaltered as the balloon expands), it is apparent that structural change is actually what much of development is all about. Change in the production structure is what admits increased roundaboutness, specialization and productivity growth, as well as the gradual expansion of more knowledge-intensive production activities, including the production of capital goods and engineering services.

Furthermore, after new sectors of economic activity have developed, changes gradually occur in the industrial organization and competitive regime of the emerging activities. New firms begin to enter these activities, markets become more contested and efforts increase to differentiate products and enhance international competitiveness. New forms of collaboration and clustering emerge among firms and they develop new patterns of interaction with each other and with other organizations in the economy, such as universities, engineering companies, trade unions, banks and insurance companies, regulatory agencies, municipalities and so forth. There is no single, universal pattern to this process. No "one-size-fits-all" model of structural transformation adequately describes all the situations that arise in real life. Variety and the dynamics of social and technological transformation are the very essence of the process. Sometimes the dynamic agent driving the creation of a new economic activity is a multinational corporation (or more than one), which is instrumental in transferring technology, opening up external markets, training domestic labour and subcontractors and enhancing domestic engineering practices. In other cases, the process is driven by familyowned SMEs or by large domestic conglomerates, which may be public, private or both. Of course, the industrial organization model and the learning process of firms and public organizations vary according to market structure and performance, the pattern of clustering and interactions between large and small firms in the economy, subcontracting practices, access to external markets and so forth. Far from being neutral in this process, the State is frequently an active agent playing a role through regulatory agencies, financial institutions, universities and municipal authorities, providing public goods, creating markets and institutions and developing the technological capabilities that act as catalysts in the process.

The differences in the way economic sectors move along the learning path and the effect of different types of government intervention in terms of inducing innovation and economic expansion came out quite clearly in the East Asian Miracle study conducted by the World Bank (World Bank, 1993). The research findings certainly surprised the World Bank researchers, who had expected conventional market forces to underlie the successful growth experience of Hong Kong, the Republic of Korea, Singapore and Taiwan Province of China. Instead, they found that the Republic of Korea was, basically, a story of cheabol and high business concentration, while the driving forces in Taiwan Province of China were SMEs with much less economic concentration, and development dynamics in Singapore were powered by TNCS. Nevertheless, in all three cases, the researchers also found significant public-sector involvement in supporting the start-up of new activities in the economy or creating the markets, institutions and domestic technological capabilities to backstop growth. The State took steps to coordinate firms and public-sector R\&D agencies and to develop the public goods needed to accelerate the process of economic development.

By the same token, the recent expansion of salmon farming and winegrowing in Chile, of geneticallymodified soybean and vegetable oil in Argentina and of the fresh flower business in Colombia all reflect quite different economic and institutional models as regards the creation of new production activities and export capabilities. They have all come about through quite different processes of institutional, social and technological transformation. In none of the three cases 
can successful expansion be put down to good macroeconomic management alone. Whereas salmon farming in Chile was driven basically by SMEs, with the State playing a proactive role through the Chilean Development Corporation (CORFO) and the Chile Foundation, the development of the soybean and vegetable oil industries in Argentina was powered by large TNCs -Monsanto among others- with less public sector intervention. Also, the soybean and vegetable oil industries in Argentina exhibit much less clustering and fewer externalities than Chilean salmon farming does.

In the early years of the development of a new industry, growth is conditioned by the rate at which new production capacity can be created (Saviotti and Gaffard, 2004). On entering the economy, new firms -local and foreign alike- build new plants, hire labour and cultivate subcontractors. They make decisions on the basis of their expected profits, which depend on the existence of a large market for them to cater for and on the global macroeconomic and institutional scenario in which they operate. The expectation of a large market creates a strong incentive to build new production capacity, but the rate at which this capacity comes on stream depends on the availability of financial resources, production knowhow, trained labour and country-and-sector-specific institutional and regulatory conditions.

The high gross margins normally yielded during the early period tend to narrow as imitations emerge and new firms enter the market. Market structure gradually shifts towards a more competitive model in which growth is determined by the rate of expansion of demand, whether domestic or foreign. The industry gradually comes to a plateau in which Schumpeterian rents diminish and price competition and product differentiation become key components of individual firms' corporate strategy. This is basically the story behind the recent expansion of salmon farming in Chile and genetically modified soybean and vegetable oil production in Argentina, as this paper will go on to discuss. In both cases, the successful development of a new economic activity has given rise to new institutions and new patterns of international competitiveness in the economy.

From this perspective, the greater or lesser success of any development process has much to do with the introduction of new production activities into the economy. Chile, in particular, went through a successful process of structural transformation in the late 1980s and the 1990s. Chile's mining, telecoms, pulp and paper industry, salmon farming and transformation of winegrowing into a highly internationally competitive, state-of-the-art industry patently exemplify an economy that has come through a successful process of structural and institutional transformation. Latest-generation plants, professional management, increasingly sophisticated regulatory institutions and local clustering developed on a par with growing penetration in world markets. The public sector, far from adopting a handsoff strategy, played an active role in this process. The Chilean process is a palpable example of structural and institutional transformation that a conventional macro account of the economy's performance simply fails to capture.

\section{III}

\section{Structural change, the emergence of new activities in the economy and the development of new sectoral regimes}

This section will examine the empirical evidence on structural changes in the economy of the region over the past three decades. Table 1 shows the changing composition of manufacturing output in Argentina, Brazil, Chile, Colombia and Mexico over the period 1970-2002. It also gives a structural change index calculated by ECLAC on the basis of its Industrial Performance Analysis Program (PADI). ${ }^{1}$

\footnotetext{
${ }^{1}$ The figures shown in table 1 were calculated using the Commission's PADI software. Thanks are due to G. Stumpo and J. Marincovic of the Division of Production, Productivity and Management of ECLAC for providing access to the data and helping with calculations.
} 
TABLE 1

Latin America (five countries): Changes in the structure of industry, 1970-2002 a

\begin{tabular}{|c|c|c|c|c|c|c|c|c|c|c|c|c|c|c|c|c|c|c|c|c|}
\hline & \multicolumn{4}{|c|}{ Argentina } & \multicolumn{4}{|c|}{ Brazil } & \multicolumn{4}{|c|}{ Chile } & \multicolumn{4}{|c|}{ Colombia } & \multicolumn{4}{|c|}{ Mexico } \\
\hline & 1970 & 1996 & 2000 & 2002 & 1970 & 1996 & 2000 & 2002 & 1970 & 1996 & 2000 & 2002 & 1970 & 1996 & 2000 & 2002 & 1970 & 1996 & 2000 & 2002 \\
\hline I & 13.2 & 9.9 & 8.6 & 6.7 & 16.2 & 25.6 & 26.0 & 26.5 & 11.4 & 10.4 & 10.5 & 10.0 & 12.3 & 10.1 & 8.7 & 9.0 & 12.0 & 14.4 & 16.4 & 15.6 \\
\hline II & 10.9 & 7.2 & 7.4 & 6.1 & 6.8 & 7.3 & 8.3 & 8.9 & 5.5 & 1.9 & 2.3 & 1.9 & 3.0 & 6.5 & 4.9 & 6.5 & 8.4 & 14.6 & 18.8 & 18.6 \\
\hline III+IV & 47.8 & 62.1 & 65.3 & 71.7 & 37.8 & 43.4 & 41.6 & 41.5 & 58.3 & 59.7 & 60.7 & 61.9 & 46.2 & 55.4 & 57.0 & 57.1 & 43.2 & 43.4 & 39.1 & 40.8 \\
\hline V & 28.1 & 20.7 & 18.7 & 15.6 & 39.2 & 23.7 & 24.0 & 23.1 & 24.9 & 28.0 & 26.5 & 26.2 & 38.5 & 28.1 & 29.4 & 27.3 & 36.4 & 27.6 & 25.8 & 25.0 \\
\hline Total & 100 & 100 & 100 & 100 & 100 & 100 & 100 & 100 & 100 & 100 & 100 & 100 & 100 & 100 & 100 & 100 & 100 & 100 & 100 & 100 \\
\hline $\mathrm{SCI}^{\mathrm{b}}$ & & 14.3 & 18.0 & 25.3 & & 18.9 & 32.3 & 27.6 & & 40.1 & 27.3 & 33.5 & & 19.4 & 29.9 & 30.9 & & 17.3 & 22.1 & 22.5 \\
\hline
\end{tabular}

Source: Industrial Performance Analysis Program (PADI), software developed by the Industrial and Technological Development Unit of the Division of Production, Productivity and Management of ECLAC.

a Structural change index, base year $=1970$.

b I = Engineering-intensive industries, excluding automobiles (International Standard Industrial Classification of All Economic Activities (ISIC) $381,382,383,385)$.

II = Automobiles (ISIC 384).

III+IV = Natural-resource-intensive industries. Foodstuffs, beverages and tobacco (ISIC 311, 313, 314); resource-processing industries (ISIC, 341, 351, 354, 355, 356, 371, 372).

$\mathrm{V}=$ Labour-intensive industries (ISIC 321, 322, 323, 324, 331, 332, 342, 352, 361, 362, 369, 390).

Table 1 shows that Argentina, Brazil, Chile and Colombia have experienced a radical transformation in their industrial structure over the past three decades, in a shift towards natural-resource-processing industries and food production. Examples of such transformation are the production of genetically modified soybeans and vegetable oil in Argentina, winegrowing and salmon farming in Chile, fresh flowers in Colombia and steel and pulp and paper in Brazil.

Mexico's structural transformation followed a different direction. In Mexico natural-resourceprocessing actually contracted as a proportion of manufacturing output, while the motor vehicle industry expanded relative to other activities. As well as motor vehicles, another industry to expand in Mexico was the assembly of television sets, video recorders and computers for the United States market, mainly from imported intermediate parts and components. Maquilatype assembly industries, which make intensive use of cheap unskilled labour, are typical of the structural transformation in other countries in the region such as Honduras, El Salvador and Guatemala, as well as Mexico.

The structural change index quoted in table 1 indicates that, of all the economies, Chile's underwent the strongest process of structural transformation in 1970-1996. In the late 1990s, the Chilean structural change index ${ }^{2}$ contracted sharply, indicating that the incorporation of new productive sectors into the economy slowed in this period. In effect, between 1998 and 2003 investment as a percentage of GDP and the economic growth rate both slowed heavily in Chile, at the same time as the structural transformation of the economy lost momentum.

As noted earlier, the start-up of new production activities is normally associated with major economic, institutional and technological changes that co-evolve within the process of economic development and influence each other in ways that are complex and as yet little understood. Seeking to shed light upon this process, there follows a brief examination of two specific cases: genetically modified soybean and vegetable oil production in Argentina and salmon farming in Chile.

\section{Genetically modified soybean and vegetable oil production in Argentina}

Transgenic crops began to be commercialized more widely in the world in 1995. By 2002 there were nearly 60 million hectares under cultivation, 14 million of them

\footnotetext{
2 The structural change index is prepared by the United Nations Industrial Development Organization (UNIDO) to measure the intensity of change in industrial structure.
} 
in Argentina. More than 90\% of the soybeans produced in Argentina today are of the genetically-modified variety and the country is the world's second largest producer, after the United States. ${ }^{3}$

The transition from conventional to genetically modified soybeans entailed a major transformation in production organization and in agricultural institutions in Argentina. Zero tillage and contract agriculture now prevail, with the traditional farmer playing a much smaller role as an agent of production organization. This role has been taken over by large independent agricultural engineering companies and subcontractors that serve a series of different farms and organize production. Risk contracts for financing and production organization are now signed with financial intermediaries and banks specializing in the financing of soybean production. The subcontracting companies use a technology package -seeds, fertilizers, herbicides- which is the private property of large TNCs such as Monsanto, Cargil, and others. ${ }^{4}$ This is clearly a departure from the pattern that prevailed during the green revolution of the $1960 \mathrm{~s}$, when agricultural technology was basically a public good distributed by State agricultural agencies.

Many new institutions (in the sense of habits of social behaviour) have emerged in the transition to genetically modified soybean in Argentina. For example, as much as $40 \%$ of the seeds used in a given agricultural season are believed to be retained from the previous year (the so-called bolsa blanca) and sold as unauthorized versions in violation of Monsanto's property rights over the technology. Monsanto did not adequately patent its technology for genetically modified soybeans and the associated herbicides at the

\footnotetext{
${ }^{3}$ Brazil is also a large producer of soybeans. Argentina, Brazil and the United States together account for nearly $95 \%$ of the total world supply of soybeans, but so far Brazil has not ventured into the genetically modified variety. Brazil's large output consists basically of conventional soybeans and the country has not approved genetically modified soybean for production (Trigo and others, 2002).

${ }^{4}$ Interestingly enough, Monsanto, the global owner of the Roundup Ready patent, opted not to register the patent for genetically modified seeds in Argentina, distributing the product instead through private arrangements with large contractors and distributors. It is believed that this reflected the company's lack of confidence in the Argentine patent system. It will also be recalled, however, that the genetically modified seeds must be used with the correct herbicide - glyphosatewhich is also owned by Monsanto. Hence, intellectual property rights and the capacity for enforcing them in a particular institutional environment constitute an important determinant of market conduct in the framework of the current industrial organization (Ablin and Paz, 2000, p. 8).
}

outset in Argentina, and the firm is now beginning legal action aimed at blocking Argentine exports of soy pellets to world markets, on the grounds that Argentina is infringing its intellectual property rights in this area.

A look at vegetable oil production from genetically modified soybeans yields a similar picture of major economic and institutional change. New state-of-theart plants built in the 1990s house highly automated catalytic production facilities whose labour productivity is tenfold that of the 1970s manufacturing technology commonly found in Argentina until quite recently. The industry's level of employment generation is quite low. The oil production sector is highly concentrated and dominated by a few large local conglomerates. Foreign capital has entered the industry only recently, with acquisitions of domestic firms.

All this indicates that the development of genetically modified soybean and vegetable oil production in Argentina involved major changes in institutions, production technology and industrial organization. Increasing returns to scale, externalities and many new technological capabilities have emerged in the economy.

\section{Salmon farming in Chile ${ }^{5}$}

The Chilean salmon farming industry has attained international competitiveness in a process that has spanned the best part of two decades. During this time, many new local and foreign firms have entered the market, sector-specific institutions and skills have developed and what was originally a quasi-cottage industry has come to be professionally managed, all of which has significantly altered production organization and international marketing practices. The cumulative impact of these changes gradually led Chile to acquire world-class status as one of the world's three main salmon farming countries, together with Norway and Scotland.

In the second stage, the industry rapidly increased in size and complexity, as large numbers of suppliers of intermediate inputs and services firms entered the market and a strong sector-specific industrial cluster was built up. The role of the State changed radically in this period: it withdrew from the role of dynamic agent inducing the inception of a new activity to concentrate

\footnotetext{
${ }^{5}$ This section is based on a previous paper prepared by the author for the World Bank (see Katz, 2004).
} 
instead on developing the regulatory framework and surveillance mechanisms that govern the sector today. The State also supported the industry in international negotiations when United States salmon farming firms made allegations of dumping against Chile.

The third stage in the industry's development was a major transformation in industrial structure, which came about through mergers and acquisitions (M\&A), changes in plant ownership, foreign direct investment (FDI) and a rapid process of internationalization.

In less than twenty years, Chile's salmon exports -consisting almost entirely of farmed fish-increased from less than US\$ 50 million in 1989 to around US $\$ 1.7$ billion today. Salmon exports now account for close to $6 \%$ of all Chilean exports. From an almost negligible $2 \%$ in 1987, the proportion of world salmon production Chile accounts for rose to nearly a third in recent years. A large number of economic, technological, and institutional forces have been involved in the process.

In the early years of salmon farming, public organizations, foreign companies and a large number of SMEs were involved. Although the public sector clearly played an important role right from the beginning, it is also true that a new generation of Chilean entrepreneurs emerged with salmon farming and began to drive the industry. Regulatory and sanitary activities, including fishing and farming permits, environmental impact surveillance and control of salmon egg imports, are performed by government agencies such as the National Fisheries Service (SERNAPESCA) and the National Environment Commission (CONAMA). The legal infrastructure to support these activities was set up in the late 1970s and the 1980s and was later substantially improved to comply with international standards (Aquanoticias, 1997a).

In the early years, the industry employed quasicottage production practices and mainly imported genetic material. Companies still prepared salmon food, a main component of aquaculture costs, every day using fresh raw materials. The conversion rate from food to fish was more than $3: 1$, i.e., three kilogrammes of fresh food per kilogramme of salmon -more than triple the industry's input-output coefficient today. Clearly, then, there have been large productivity gains and individual firms have undergone major learning processes (Aquanoticias, 1997 b, p. 24). Such examples abound in relation to cultivation tanks, vaccines, final product processing and so forth (Aquanoticias, 1998, p. 12).
By the late 1990s, Chilean salmon farming had attained many of the features of a mature ${ }^{6}$ oligopoly it has today. World prices for salmon fell significantly in the second half of the 1990s, approaching the industry's long-term unit production costs. Gross margins narrowed as competition and contestability increased in salmon markets. The industry's technological and competitive regime became more demanding as a result of mergers and acquisitions, which substantially increased average company size, capital intensiveness and technological sophistication and heightened business concentration.

A number of general conclusions may now be derived from the foregoing discussion of economic, technological and institutional factors underlying the inception of genetically modified soybean and vegetable oil production in Argentina and salmon farming in Chile.

In both Argentina and Chile, the structural change of the past two decades has been strongly biased towards natural-resource-processing activities, mainly agricultural products and foodstuffs, pulp and paper, fisheries, gas and petroleum. This structural transformation raises many new questions over the impact of the process and the biological, genetic and environmental consequences of growth based on more intensive exploitation of natural resources.

Clearly, the sustainable exploitation of agricultural land, marine resources, forests or mines demands a basic knowledge and understanding of such disciplines as biology, genetics, marine sciences, mineralogy, immunology and many others related to the conservation, depletion rate and rational exploitation of these resources. Some of this knowledge and understanding can be developed through the use of offthe-shelf knowledge and technology available in the international market. Importantly, however, much of the knowledge base needed for these activities is highly country-and-location-specific, since the physical, biological and ecological conditions vary significantly in different production locations. This is also true of the capital goods and intermediate inputs needed in each

\footnotetext{
${ }^{6}$ What a mature industry is, and how the notion applies to salmon farming, was clearly illustrated in a recent public address given by Torben Petersen, Chief Executive Officer of Fjord Seafood Chile (a subsidiary of the Norwegian company of the same name). He said, "The real maturation process begins when we see that company actions are aimed at the markets and not at production, in other words, when salmon farming growth is determined by its market and not by its production" (Aquanoticias, 2004).
} 
case. In other words, the metaphor of ready-made production functions waiting to be lifted from some sort of international technology shelf does not really apply to the scenarios that concern us. Applied research and development efforts are needed to adapt internationally available capital goods and intermediate inputs to local conditions and to design and bring on stream others that are specific to particular locations. Public sector R\&D organizations, university-based research laboratories and domestic engineering firms should be steered into technological missions aimed at developing new country-and-location-specific knowhow and production organization technologies.

An examination from this perspective prompts the usual questions about market failure, lack of public goods and the imperfect appropriability of benefits. The need for government intervention is evident if Latin American countries are to exploit their natural resources in a rational and sustainable manner. Undoubtedly, good macroeconomic management is a sine qua non for success, but what is crucial -and what the public sector must carefully consider if Latin American countries are to properly realize the growth potential embodied in their rich natural-resource endowment- is the technological, economic and institutional complexity of each particular situation. This leads to the examination of how technologygeneration capabilities have evolved so far in the region and what needs to be done on this front in the years ahead.

\section{IV}

\section{Domestic technology-generation efforts}

\section{in Latin America}

Latin American firms have not so far shown much interest in being part of technology generation efforts to develop proprietary technology. Unlike successful firms in other catching-up economies, Latin American firms have not, until now, given much indication of significantly expanding in-house R\&D activities nor of strengthening links with local universities, public sector labs and engineering firms to develop new product designs or new process technologies. Nor have they attempted to export "pure" forms of technology or know-how resulting from their internal learning processes, as Swedish and Finnish firms have done in the pulp and paper sector, Netherlands and Scottish firms in salmon farming and dairy products, and Canadian firms in cooper refining. ${ }^{7}$ Most Latin American firms seem to be content with a more passive stance on those matters.

\footnotetext{
${ }^{7}$ This said, interestingly enough, Argentine, Brazilian and Mexican metalworking firms and engineering consultants exported pure technology in the form of turn-key plants and licensing contracts in the 1970s and early 1980s. This went unnoticed in the wave of highly derogative criticism of inward-oriented industrialization in the 1980s. On the topic of Latin American technology exports, see Amsdem (2001).
}

Is it simply a matter of time until Latin American companies eventually work up an appetite for a more dynamic take on this front, or is this a long-term pattern of behaviour that will need a different public policy approach to inject technological dynamism into the business sector of the economy? We believe this latter to be the case, as explained below.

Latin American firms' lack of involvement in technology generation appears to be a deeply-rooted feature of local production organization models deriving, on the one hand, from the fragmented and inefficient public sector knowledge-generation infrastructure Latin American countries erected during the post-war period and, on the other, from the lack of incentives for firms to expand in-house technologygeneration efforts and R\&D expenditure. ${ }^{8}$

Spending on R\&D has always been low in the region, usually no more than half a percentage point of

\footnotetext{
${ }^{8}$ Many Latin American firms systematically engage in adaptive knowledge-generation for process and product improvement. Although much of this involves incremental knowledge generation and changes in production organization routines, these activities are not normally captured by conventional surveys measuring R\&D efforts at the individual company level. Being informal, efforts of this sort and the spending they entail are normally underreported.
} 


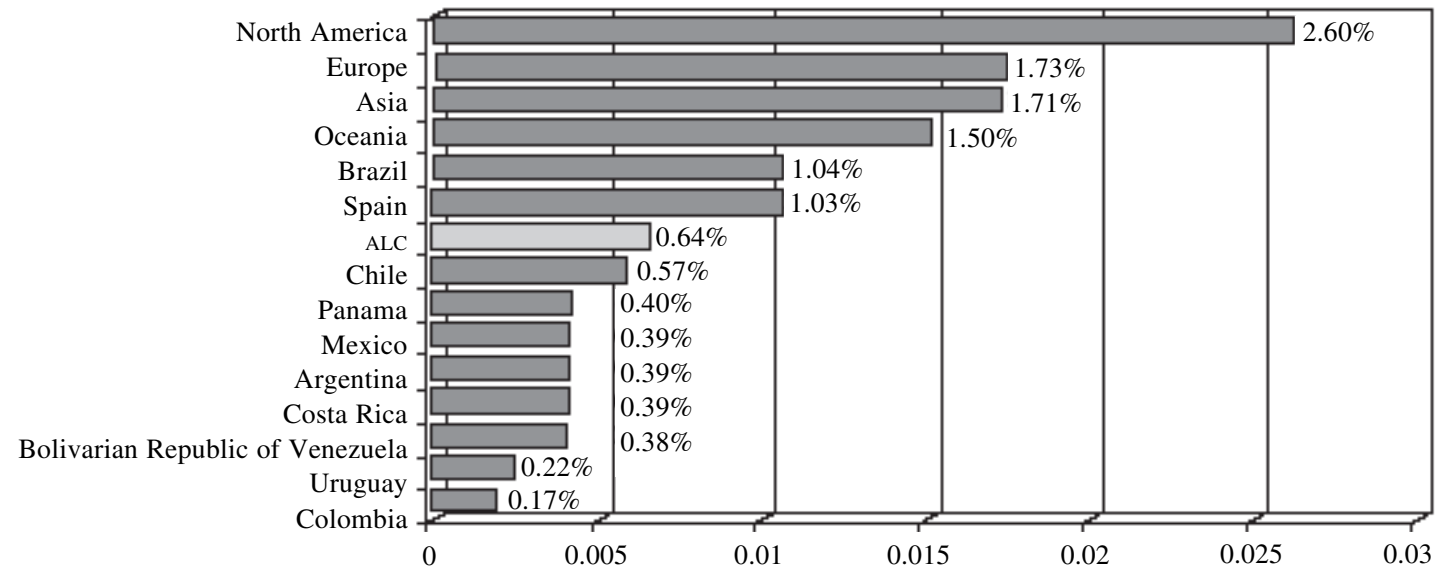

Source: prepared by the author.

${ }^{\mathrm{a}} \mathrm{ALC}=$ Latin American and the Caribbean.

GDP. It varies between a third and a quarter of more advanced countries' allocations to new technology development, as figure 1 indicates. Moreover, $80 \%$ of total R\&D expenditure has traditionally been carried out by the State in public sector laboratories and State universities.

We still know very little about why public or private organizations and institutions work well (or not) as generators and disseminators of knowledge in any given country. We do know, however, that markets do not perform well in this respect, as a result of imperfect information, weak property rights, lack of human capital endowments and many other reasons. Much of the lack of individual firm involvement and inefficient country-wide behaviour as regards technology generation and diffusion may be put down to poor organizational design, little effort to coordinate and absence of the right kind of market and non-market incentives. How much a country spends on R\&D activities is certainly an important indicator of its commitment to technology issues, but even more important than the expenditure itself is the efficiency of local $R \& D$ organizations and laboratories in transforming those resources into technological knowhow for the production of goods and services. Poor functioning and slack performance on the part of institutions and an inadequate incentive regime are the main reasons for the negligible part domestic technology sources have played so far in innovation in Latin America. A long road remains to be travelled before domestic firms, universities, engineering consultants, banks and insurance companies, professional associations, municipalities and government officials in general learn how best to deal with questions of innovation and domestic technological development. How can venture capital markets capable of financing innovation efforts be created? How can would-be entrepreneurs graduating from university laboratories be oriented? How can innovation be made affordable to sMEs? What role could technology parks or incubators play in this connection? These and many related questions have yet to be answered satisfactorily in most Latin American countries.

Furthermore, as noted earlier, when growth is based on the exploitation of natural resources further complications arise as a result of the unique economic, institutional and technological circumstances surrounding the sustainable exploitation of such resources. Some are renewable and others are not. The opportunity cost associated with depletion and renewal varies hugely from one field of economic activity to another, depending on biological and environmental circumstances. Firms' economic behavior is influenced by the cost of exploration for new sources of supply, the biological life cycle and natural rate of depletion of each location, the cost of environmental conservation, the nature of the regulatory framework and system of property rights in which the resource is to be exploited, and so forth. 
These circumstances affect the planning horizon with which firms enter the activity, the long-term profit rates underlying investment programmes and the strategy according to which each firm decides to stay in or exit the activity. The political climate that develops in each country in relation to natural-resource exploration/exploitation also bears heavily on company strategy.

\section{Policies for technological development and innovation}

To achieve better growth performance and enhance international competitiveness it is essential to expand domestic R\&D efforts and heighten the efficiency with which domestic knowledge-generation activities are organized and performed in the economy.

In order to expand knowledge-generation and diffusion activities Latin American countries have to tackle financial, human capital and institutional constraints. In Latin America, national innovation systems are still highly fragmented and uncoordinated pieces of social machinery, whose various parts must function in a more coordinated manner in order to expand productivity growth and increase the rate of innovation.

It is crucially important for the countries to increase their resource allocations for $\mathrm{R} \& \mathrm{D}$, but it must also be a high priority to enhance the productivity of the resources now allocated to knowledge- and technologygeneration activities. The private sector needs to be persuaded to expand its commitment to R\&D and technology absorption. Strengthening intellectual property rights and providing financial incentives are possible ways to achieve this. It is necessary to establish adequate judicial mechanisms to enforce property rights, given the weak legal environment in this respect in most of the region's countries today. This should be undertaken within an appropriate framework of competition policies that would prevent monopolistic market exploitation by those firms whose patents are to be strengthened.

The public sector certainly has an important role to play through universities and R\&D laboratories, simply exploring the frontier of knowledge as regards the sustainable exploitation of natural resources, i.e., molecular biology and biotechnologies, genetics and immunology, and human and animal health sciences and biotechnologies (including those related to vaccines and pharmaceuticals), as well as in the expansion of computer sciences and information technologies, which are fundamental in the transition to a learning economy. However, the private sector needs to be cajoled into taking a more hands-on, committed approach to the development and adoption of new technologies downstream from the basic sciences, if Latin American countries are to attain a more rapid pace of innovation and technological progress. This is essential to help the countries to expand their exports of products with higher domestic value added, on the one hand and, on the other, to provide the public goods and services for much broader-fronted environmental protection in the transition to a more natural-resource-intensive production frontier.

Other members of the national innovation system -such as banks or insurance companies, universities and municipal authorities- should also be induced to engage more actively in domestic technological matters, exploring new mechanisms to develop venture capital markets, schemes to build up human capital and institutional arrangements related to diffusion of technology in the economy and the protection of property rights and the environment. New forms of venture capital markets should be explored with a view to the financing of R\&D efforts. In many countries, governments are actively seeking out alternative institutional modalities through which pension fund systems could be prevailed upon to take a more active role in this direction. Another possibility to consider is for the government to act as a second-tier financial intermediary, decentralizing the management of public R\&D funds to commercial banks and inducing the banking system to be more active in financing R\&D activities. Around the world, a number of countries are successfully developing new forms of social engineering in this connection. 
The creation of technology parks and incubators should be explored in fields such as agribusiness, aquaculture, novel uses of timber in housing and furniture and other fields downstream from the rich natural resources now being exploited in the region. Stimuli should be provided for firms offering computer software and engineering services for SMEs, since software providers currently seem to be catering almost exclusively for the needs of large firms, thereby making computer-based production organization technologies almost inaccessible for most SMEs.

Strengthening the production fabric at the local and municipal level requires many new forms of collective action and public sector coordination. The rationale for this is that acting at the local level generates strong network externalities. The development of industrial clusters around the exploitation of natural resources creates opportunities for collaborative efforts among municipalities, regional universities, research centres and small family enterprises, exploring forms of interaction that remain essentially untapped in the region in areas such as agribusiness and pharmaceutical products. Biotechnologies seem to be opening a major window of opportunity in this area.

Admittedly, it is a complex matter to generate local-level collective action and greater coordination efforts for producing and disseminating technological know-how. Demand subsidies and public brokers could be used to help SMEs develop R\&D and innovation projects for submittal to public $R \& D$ financing agencies and banks. Fruitful experiences of this type conducted recently by Brazil, Chile and Costa Rica suggest that efforts to develop capital markets may play a key role at the local and municipal level. Risk-sharing contracts, public tenders and competitive bidding should be explored in order to spur private firms' interest in technology-generation efforts.

The matter of expediting the transition to a knowledge-based economy should be a strategic policy issue for the immediate future. A broader availability of ICT-related public goods should have a strong positive impact in terms of productivity growth and of equitable access to digital goods and services in society. This is a prominent subject on the policy agenda of many countries that are making progress in the expansion of digital infrastructure in schools, hospitals and municipalities in the world today. This process could be combined with stronger support for the development of domestic software providers and contents industries that cater specifically to the health, educational and municipal needs of regional and local communities. Expanding internet connectivity and narrowing the international and domestic digital divide will take careful intervention not only in technology and finance, but also in the regulatory sphere (in relation to the functioning of the telecoms industry). Issues of compatibility of standards and network creation should be addressed in the transition to a digital economy.

Which policies will or will not work to enhance the technological performance of any given country is difficult to assess ex ante. The induction of knowledge generation and diffusion efforts in the economy and the expansion of equitable access to many of the goods and services necessary for the transition to a knowledgebased digital economy are highly country-specific matters. No one-size-fits-all policy is likely to succeed. Evidently, there is no way round trial and error and a highly pragmatic approach to these issues. The experiences of the dynamic East Asian economies, whose successes and failures as regards the design and implementation of technological policies are reported in the academic literature, and the cases of Ireland, New Zealand and Israel all confirm that there are no universal recipes in this field. Different forms of capitalism exist around the world and it is time for Latin American governments to actively seek out their own brand, phasing out the old Washington-consensus ideas of the 1980s and starting to experiment with country-specific interventions aiming at developing a more vibrant national innovation system. 


\section{Bibliography}

Ablin, E. y S. Paz (2000): Productos transgénicos y exportaciones agrícolas. Reflexiones en torno a un dilema argentino, Buenos Aires, Dirección de Negociaciones Económicas y Cooperación Internacional.

Amsdem, A. (2001): The Rise of "the Rest": Challenges to the West from Late Industrializing Economies, Nueva York, Oxford University Press.

Aquanoticias (1997a): november. (Journal of the Chilean Salmon farming industry).

(1997b): july.

(1998): april-may.

(2004): 18 may.

Banco Mundial (1993): The East Asian Miracle: Economic Growth and Public Policy, Washington, D.C.

Harberger, A. (1998): A vision of the growth process, American Economic Review, vol. 88, $\mathrm{N}^{\circ}$ 1, Nashville, Tennessee, American Economic Association, march.
Katz, J. (2002): Efficiency and equity aspects of the new Latin American economic model, Economics of Innovation and new Technologies, vol. 11, № 4-5, Londres, Routledge.

(2003): Market oriented reforms, globalization and the recent transformation of Latin American innovation systems, Research Policy, Amsterdam, Elsevier.

(2004): Economic, institutional and technological forces inducing the successful inception of salmon farming in Chile, documento preparado para el Banco Mundial.

Saviotti, P. y J.L. Gaffard (2004): Innovation, structural change and growth, Revue économique, vol. 55, París, Presses de Sciences Po, november.

Trigo, E., A. López y otros (2002): Los transgénicos en la agricultura argentina. Una historia con final abierto, Buenos Aires, IICA/ Libros del Zorzal. 